\title{
Az innovációs rendszerek irodalmának áttekintése
}

\author{
Varga-Csajkás Anna \\ Pécsi Tudományegyetem
}

\begin{abstract}
A TANULMÁNY CÉLJA
Mára általánosan elterjedt az innováció rendszer-szerủ felfogása, miszerint az innováció nem elszigetelt vállalatok teljesítményének eredménye, hanem egy adott intézményi környezeten belül a különböző szereplők interakciói során megvalósuló jelenség. A tanulmány célja ennek a koncepciónak a bemutatása, és a nemzeti, regionális, technológiai, valamint szektorális innovációs rendszerek szakirodalmon belül elfoglalt pozíciójának feltárása. Ezen felül arra keressük a választ, hogy milyen új kihívásokkal kell megküzdenie az innovációs rendszerek elméletének ahhoz, hogy továbbra is releváns elemzési keret maradjon.
\end{abstract}

\begin{abstract}
ALKALMAZOTT MÓDSZERTAN
A tanulmány egy szakirodalmi elemzés, amely három részből épül fel. Elöször bemutatásra kerül az innovációs rendszerek négy típusa a különböző irányzatokat megalapozó publikációk alapján. Ezután bibliometriai eszközökkel elemezzük a szakirodalom alakulását és a különböző innovációs rendszer-típusok egymáshoz való viszonyát. Végül az innovációs rendszerek új elméleti kihívásait ismertetjük.
\end{abstract}

\section{LEGFONTOSABB EREDMÉNYEK}

Az eredmények rávilágítanak arra, hogy alapvetően dinamikusan növekedett az elmúlt három évtizedben az innovációs rendszerek irodalma, de az utóbbi néhány évben megtorpanás tapasztalható. Ez alapján úgy tủnik, hogy az innovációs rendszer koncepció már túl van a legdinamikusabb terjedésén. Emellett számos kihívással kell megküzdenie annak érekében, hogy releváns elemzési keret maradjon. Ehhez kapcsolódóan a társadalmi és környezeti hatásokat is figyelembe vevő irányzatok integrálására több megközelítés is született.

\section{GYAKORLATI JAVASLATOK}

Az innovációs rendszer, mint elemzési keret megújításra szorul, de még mindig széles körben elterjedt, releváns koncepcióról van szó. Az eddigi törekvések mellett szükség van további kutatásokra, amelyek arra irányulnak, hogy az innováció szélesebb körủ értelmezése is lehetővé váljon ebben a keretrendszerben.

Kulcsszavak: innovációs rendszerek, irodalomelemzés, bibliometriai elemzés

Köszönetnyilvánitás: Jelen publikáció az Európai Unió, Magyarország és az Európai Szociális Alap társfinanszírozása által biztosított forrásból az EFOP-3.6.2-16-2017-00017 azonosítójú „Fenntartható, intelligens és befogadó regionális és városi modellek" címü projekt keretében jött létre.

DOI: 10.15170/MM.2020.54.KSZ.I.01 


\section{BEVEZETÉS INTRODUCTION}

Az innováció rendszerszerủ szemlélete az 1980-as évek végén jelent meg, amikor felismerték, hogy az új termék vagy technológia nem elszigetelten müködő vállalatok tevékenységének az eredménye, hanem különböző szereplök együttmüködése során jön létre. Ezek a szereplők lehetnek különböző vállalatok, egyetemek, kutatóintézetek, állami intézmények vagy bármilyen szervezet, ami szerepet játszik az innováció folyamatában. Az intézményi környezet, amelyben múködnek és kapcsolatba lépnek egymással, meghatározó jelentőségű az innováció szempontjából. Ide tartoznak az informális intézmények, mint a szokások és normák, valamint a formális intézmények, mint a törvények és egyéb szabályozások.

Az IR koncepció a kezdetektől párhuzamosan fejlődött mint elméleti irányzat és mint szakpolitikát támogató eszközrendszer (Lundvall 2007). Ennek megfelelően az innovációs rendszerek koncepciója egy nagyon rugalmas megközelítés, ami miatt nem jellemző rá a gazdasági elméletektől elvárt koherencia és tudományos szigor (Weber \& Truffer 2017). Az innovációs rendszerek szakirodalma rendkívül kiterjedt, multidiszciplináris jellegü, ezért manuálisan összegyüjteni a releváns publikációkat és azokat szisztematikusan elemezni lehetetlen (Liu et al. 2015). Ehelyett az egy-egy specifikus kérdésre koncentráló irodalomelemzések (Vas - Bajmócy 2012, Watkins et al. 2015, Weber -Truffer 2017, Asheim et al. 2011, 2016), valamint az online adatbázisokra épülő szisztematikus irodalomelemző tanulmányok (Doloreux \& Gomez 2017, Pino \& Ortega 2018) és bibliometriai elemzések (Fagerberg \& Sapprasert 2011, Liu et al. 2015, Rakas \& Hain 2019) terjedtek el. Magyar nyelven Vas és Bajmócy (2012) készített irodalomelemzést, amelyben az evolúciós elméleti alapokat kiemelve áttekintették az innovációs rendszerek 25 évét. További magyar nyelvü összefoglaló munka Inzelt és Bajmócy által szerkesztett (2013) kötet, amelyben az innovációs rendszerben kialakuló kapcsolatok, a vállalatok és iparágak szerepe, valamint a szabályozás és szakpolitika kérdése köré csoportosulnak a tanulmányok. Ezen kívül Inzelt (2015) cikkgyűjteménye segít áttekinteni az elmúlt 30 év magyar innovációs folyamatait empirikus kutatásokon keresztül.

A tanulmány további része négy fejezetre oszlik. Elöször bemutatásra kerül az innovációs rendszerek négy típusa a különböző irányzatokat megalapozó publikációk alapján. Ezután alapszintü bibliometriai eszközökkel elemezzük a szakirodalom alakulását és a különböző innovációs rendszer-típusok egymáshozvaló viszonyát, amit azinnovációs rendszerek új kihívásainak ismertetése követ. A tanulmány a fő megállapítások összegzésével zárul.

\section{AZ INNOVÁCIÓS RENDSZEREK NÉGY TÍPUSA THE FOUR TYPES OF INNOVA- TION SYSTEM}

A nemzeti innovációs rendszerek (NIR) elmélete jelent meg elsőként a szakirodalomban, ezért az innovációs rendszerek (IR) megszületése is ehhez köthető. Később a gazdasági tevékenység térbeli tömörülésének figyelembevételével kialakult a regionális innovációs rendszerek (RIR), az iparágak sajátosságainak hangsúlyozása kapcsán a szektorális innovációs rendszerek (SIR), valamint az egyes technológiákat fókuszba állító, technológiai innovációs rendszerek (TIR) koncepciója.

\section{Nemzeti innovációs rendszerek National Systems of Innovation}

A nemzeti innovációs rendszerek fogalmát Freeman, Nelson és Lundvall munkásságához köthetjük. A három kutató megközelítésében sok közös elem található, viszont a rendszer más-más aspektusait hangsúlyozzák. Freeman (1987) Japánról szóló könyvében a nemzetre jellemző alrendszerekre, és azok interakcióira koncentrál. Definíciója szerint „A közösségi és magénszektor azon intézményeinek hálózata, amelyek tevékenysége és interakciói kezdeményezik, átveszik, módosítják és terjesztik az új technológiát, nemzeti innovációs rendszerként írható le.” Freeman $(1987,1)$ Nelson az innováció fogalmát tágan értelmezi, ezért beleért minden termék- és folyamatinnovációt, ami új a vállalat a nemzet vagy a világ számára. A rendszerre úgy tekint, mint intézményi szereplők halmazára, amelyek együttesen befolyásolják az innovatív teljesítményt (Nelson 1993, 4-5). Lundvall (1992) megközelítése az interaktív tanulást helyezi a középpontba. Megkülönbözteti az innovációs rendszerek szük és tág értelmezését. Eszerint szüken értelmezve csak azok a szervezetek és intézmények tartoznak a rendszerhez, amelyek közvetlenül érintettek a felfedezés folyamatában. Tág értelemben véve viszont a gazdasági struktúra és az intézményi környezet minden eleme beletartozik, ami hat az innovatív folyamatra (Lundvall 1992, 12). 


\section{Regionális innovációs rendszerek Regional Systems of Innovation}

A RIR (Cooke 1992, Cooke et al. 1997, Braczyk et al. 1998) koncepció kialakulása során a NIR-ek elméletén kívül egyéb területi innovációs elméletek is szerepet játszottak. Az iparági körzetek, az innovatív miliő és a klaszterek mind megerösítik az innovációs folyamatok regionális szinten való vizsgálatának jelentőségét.

A RIR megközelítés alapja, hogy ,az ágensek közötti gazdasági és társadalmi interakciók, a közösségi és magán szektoron átívelően megteremtik és terjesztik az innovációt a régión belül, beágyazódva a szélesebb nemzetközi és globális rendszerbe" (Asheim et al. 2011, 878). Fontos tehát a térbeli koncentráció, de a RIR szemlélet elengedhetetlen eleme a régiók nyílt jellege. Szűk értelemben a RIR két részből, a tudás létrehozására és terjesztésére, valamint a tudás alkalmazására és kiaknázására irányuló alrendszerből áll. Tág értelemben viszont minden regionális gazdasági, társadalmi és intézményi tényező beletartozik a rendszerbe, ami hat a vállalatok innovativitására (Asheim et al. 2016).

\section{Technológiai innovációs rendszerek Technological Systems of Innovation}

A TIR olyan elemek összességeként értelmezhetö, amelyek aktívan hozzájárulnak az adott technológiai területhez (Bergek et al. 2015). A fogalom megszületése Carlsson és Stankiewicz 1991-es tanulmányához kötődik, amelyben még a technológiai rendszerek kifejezést használták, de a nemzeti innovációs rendszerekhez viszonyítva értelmezték azt. „A technológiai rendszer ágensek hálózataként definiálható, amelyek meghatározott gazdasági/ iparági területen, adott intézményi és infrastrukturális keretek között interakcióba lépnek egymással és érintettek az adott technológia létrehozásában, terjesztésében és hasznosításában." (Carlsson \& Stankiewicz 1991, 111) A TIR keretei között elemezhetők érett iparágakat és egy-egy új technológia kialakulása és terjedése is (Bergek et al. 2015). A NIR megközelítéssel szemben többnyire a technológia hasznosítását helyezik a középpontba az új tudás létrehozása és terjesztése helyett. A TIR vizsgálati módszerének sajátossága a folyamatszemlélet, ami eltér az IR-ek többi változatára jellemző strukturális megközelítéstöl. Ennek lényege, hogy nem a rendszer szereplöire és az intézményi környezetre helyezik a hangsúlyt, hanem a kulcsfontosságú folyamatokra (Bergek et al. 2008).

\section{Szektorális innovációs rendszerek Sectoral Systems of Innovation}

A SIR-ek kialakulásának motivációja az volt, hogy többdimenziós, integrált és dinamikus megközelítéssel lehessen vizsgálni a különböző iparágakat (Malerba 2002). A megközelítés az IR-ek irodalmán kívül az iparági életciklussal foglalkozó tanulmányokra is épít (Malerba \& Adams 2014). A rendszer-szerú megközelítésböl Lundvall (1992), Carlsson (1995) és Edquist (1997) munkái alapján azt emelik ki, hogy az innováció egy interaktív folyamat, amelyben különböző szereplők érintettek, akik között nem csak cégek, hanem egyéb szervezetek is szerepelnek, akik viselkedését az intézményi környezet nagyban befolyásolja. $\mathrm{Az}$ innovációs rendszerek elméletének további jellemzői, amelyekre épít a SIR, hogy nagy hangsúlyt kap az interdiszciplináris megközelítés és a történeti szemlélet, valamint a tanulás innovációban betöltött központi szerepe (Malerba 2002). Breschi és Malerba $(2005,131)$ az iparági innovációs rendszereket úgy definiálta mint „A szereplők által alkotott olyan csoport, amelyben a szereplők aktívan részt vesznek egy adott iparág termékeinek kifejlesztésében és gyártásában, az iparági technológia előállításában és felhasználásában.”

\section{AZ INNOVÁCIÓS RENDSZEREK IRODALMÁNAK BIBLIOMETRI- AI ELEMZÉSE BIBLIOMETRIC ANALYSIS OF INNOVATION SYSTEMS LITE- RATURE}

A Web of Science alapgyüjteményében szereplő publikációkat alapul véve megvizsgáltuk az IR-ek szakirodalmának alakulását. Azokat a publikációkat vettük figyelembe, amelyek címében, kulcsszavai között vagy absztraktjában szerepelt az ,innovation system(s)" vagy a ,system(s) of innovation” kifejezés. 6378 ilyen munka található az adatbázisban 2020 januárjában, amelyek közül 4150 publikáció valamely folyóiratban jelent meg. 


\section{Az IR publikációk számának alakulása The development of the number of IS publications}

Az IR témában született publikációk száma néhány év kivételével évről évre növekedett a koncepció megjelenésétöl 2017-ig, viszont az utóbbi években csökkenés jellemző. A négy irányzat közül a nemzeti és a regionális innovációs rendszerek kiemelkednek a publikációk számosságának tekintetében. A két kevésbé elterjedt koncepció közül a technológiai rendszerekhez köthető közlemények száma az utóbbi években - 2019 kivételével - dinamikusan növekedett, ezzel szemben a SIR publikációk számossága alacsony szinten maradt.

1. ábra: Az évente megjelenő IR publikációk száma 1990-2019-ig

Figure 1. New IS publications per year from 1990 to 2019
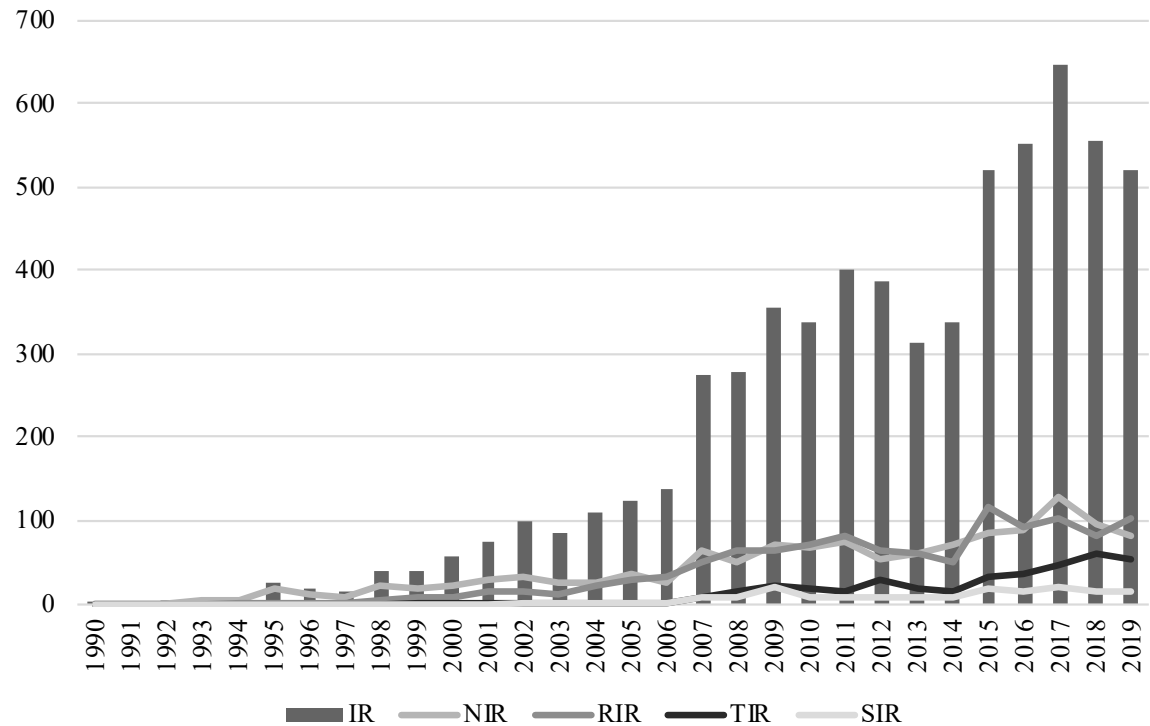

Forrás: a Web of Science adatai alapján saját szerkesztés

Az 1. ábrából kiderül, hogy a négy irányzathoz tartozó publikációk nagyjából csak a felét teszik ki a beazonosított közleményeknek, ami azért lehetséges, mert olyan tanulmányok is megkaphatták az IR kulcsszót, amelyek nem építenek kifejezetten a négy típus valamelyikére.

\section{A leggyakoribb kulcsszavak vizsgálata Investigation of the most common keywords}

A vizsgált publikációkban leggyakrabban megjelenő kulcsszavak alapján következtetni lehet az IR irodalom által feldolgozott kutatási területekre. Ezeket évtizedenként vizsgálva azt is láthatjuk, hogy a témák népszerüsége hogyan változott (1. táblázat). 


\section{1. táblázat: A leggyakoribb kulcsszavak az IR-ek szakirodalmában évtizedenként Table 1. The most common keywords in IS literature per decades}

\begin{tabular}{|l|l|l|l|}
\hline & $\mathbf{1 9 8 7 - 1 9 9 9}$ & $\mathbf{2 0 0 0 - 2 0 0 9}$ & $\mathbf{2 0 1 0 - 2 0 1 9}$ \\
\hline 1 & innováció & innováció & innováció \\
\hline 2 & vállalat & innovációs rendszerek & innovációs rendszerek \\
\hline 3 & technológia & technológia & szakpolitika \\
\hline 4 & NIR & tudás & tudás \\
\hline 5 & hálózatok & RIR & RIR \\
\hline 6 & szakpolitika & hálózatok & technológia \\
\hline 7 & ipar & szakpolitika & rendszerek \\
\hline 8 & globalizáció & rendszerek & dinamika \\
\hline 9 & versenyképesség & ipar & K+F \\
\hline 10 & innovációs rendszerek & vállalat & keretrendszer \\
\hline
\end{tabular}

Forrás: a Web of Science adatai alapján saját szerkesztés

Az innovációs rendszerek bő első évtizedében az „,innováció” mellett a „vállalat” és az „,ipar” kulcszszó is kifejezetten gyakori volt, a 2010-es években viszont már nem szerepelt az első tíz között. Ebböl arra következtethetünk, hogy a hagyományosan az innovációhoz kötődő kifejezések (innováció + ipar/cég) jelentősége csökkent más, kifejezetten az IR keretében vizsgált kulcsszavakkal szemben. A ,technológia” viszont folyamatosan szerepel a leggyakoribb kifejezések között, ami nem csoda, mivel az IR kutatások jelentős részében az innovációt egy új technológia kifejlesztéseként értelmezik. Ráadásul a TIR-ek egyre népszerübb irányzattá váltak az elmúlt évtizedben. A ,szakpolitika” kifejezés szintén mindvégig a legnépszerübb kulcsszavak között szerepelt, ami érthető, mivel az IR kezdetektől párhuzamosan fejlődött mint elméleti irányzat és mint szakpolitikát támogató eszközrendszer (Lundvall 2007). Az utóbbi évtizedben pedig szinte a leggyakoribb kulcsszóvá vált, amiben közrejátszhatott, hogy az IR elemzésekbe újabban bekerült társadalmi és környezeti aspektusok a szakpolitikai újszerủ feladataira hívják fel a figyelmet (Tödtling \& Trippl 2018). A „tudás” csak 2000 után vált az egyik leggyakoribb kulcsszóvá, de megőrizte az erős pozícióját 2010 után is, ami arra utal, hogy a tudás termelése és elosztása mára erősen összekapcsolódik az IR elemzésekkel. Ugyanez igaz a „RIR” fogalmára is, ami pont ellentétes trendet mutat a
„NIR” említésével. A RIR megközelítés erősségét az adja, hogy a regionális tudományokba integrálódott az innováció rendszer szerủ megközelítése. A „globalizáció” jelentőségét már a NIR megjelenésekor figyelembe vették, ami látható a kulcsszó kétezres évek előtti népszerüségéből. Időközben azonban más kérdések is bekerültek az elemzések fókuszába, mint például a dinamika vagy a hálózatok, amivel kiszorult a 10 legnépszerúbb kulcsszó közül, de ez nem jelenti azt, hogy ne lenne még mindig fontos kérdés az innováció globális jellege. Ezt támasztja alá a globális innovációs rendszerek elméletének megjelenése is (Binz \& Truffer 2017). Látható, hogy a „dinamika” kifejezés csak az elmúlt tíz évben került a leggyakoribb kulcsszavak közé, ugyanis sokáig a rendszer elemeinek statikus leírására koncentráltak a kutatások.

Ha az innovációs rendszerek négy típusa alapján végzünk összehasonlítást, akkor szembetűnő, hogy a két területi alapú innovációs rendszer vizsgálatánál (2. táblázat) nagyon hasonló kulcsszavakkal találkozunk. 


\section{2. táblázat: A leggyakoribb kulcsszavak az IR-ek szakirodalmában IR-típusok szerint Table 2. The most popular keywords in IS literature according to IS types}

\begin{tabular}{|l|l|l|l|l|}
\hline & NIR & RIR & TIR & SIR \\
\hline 1 & NIR & RIR & TIR & SIR \\
\hline 2 & innováció & innováció & dinamika & innováció \\
\hline 3 & technológia & tudás & többszintủ perspektíva & dinamika \\
\hline 4 & K+F & szakpolitika & keretrendszer & rendszerek \\
\hline 5 & szakpolitika & klaszterek & átmenet a fenntarthatóság felé & IR \\
\hline 6 & tudás & rendszerek & szakpolitika & ipar \\
\hline 7 & IR & hálózatok & IR & szakpolitika \\
\hline 8 & rendszerek & K+F & diffúzió & technológia \\
\hline 9 & növekedés & teljesítmény & fenntarthatóság & diffúzió \\
\hline 10 & teljesítmény & technológia & megújuló energiaforrások & keretrendszer \\
\hline
\end{tabular}

Forrás: a Web of Science adatai alapján saját szerkesztés

Mind nemzeti, mind regionális szinten gyakori az „innováció”, „technológia”, „K+F”, „,szakpolitika”, „tudás”, „rendszerek” és „teljesítmény” kifejezés. Ebböl is látszik, hogy a két területi alapú IR típus közelítésmódja sokban hasonlít egymásra. Egy régió vagy nemzet esetén gyakran vizsgálják az innovációs rendszer elemeit, hogy hogyan jön létre és terjed az új tudás, valamint, hogy hogyan alakul a rendszer teljesítménye és ennek kapcsán milyen szakpolitikai beavatkozások, például $\mathrm{K}+\mathrm{F}$ támogatások lehetnek szükségesek. Mindkét esetben igaz, hogy általában technológiai innovációk állnak az elemzés középpontjában. A RIR viszont nem csak annyiban különbözik a NIR-töl, hogy kisebb területi egységet foglal magába, hanem a földrajzi közelségböl adódó sajátosságai is vannak, ami eltérő kutatási irányokhoz vezet. A „klaszter” kulcsszó, vagyis egy adott iparág szereplőinek földraji koncentrációja is erre utal.

A szektorális innovációs rendszerek elméleti alapjai között szerepel a NIR megközelítés, amit alátámaszt, hogy a legnépszerübb kulcsszavainak fele megegyezik a nemzeti változatéval. Látható viszont, hogy a SIR megközelítés az iparági életciklussal foglalkozó irányzatokra is épít, ami magyarázza az ,ipar”, ,dinamika” és „,diffúzió” kifejezések megjelenését. A TIR-ek viszont távol állnak a területi alapú innovációs rendszerektől, és inkább a szektorális változattal vannak közös vonásaik a kulcsszavak előfordulása alapján. Ilyenek a „dinamika”, „diffúzió” vagy a „keretrendszer” szavak. Ezekből a kulcsazvakból az is látható, hogy a TIR nem csak a rendszer eleminek statikus leírására koncentrál. A fő kutatási irányokról sokat elárul, hogy a leggyakoribb kulcsszavak között szerepel a „,enntarthatóság”, a „többszintű perspektíva” és a „megújuló energiaforrások”.

$\mathrm{Az}$,innováció” mellett a „szakpolitika” és a „technológia" tekinthető olyan fogalomnak, ami megkerülhetetlen az IR szakirodalmon belül, ugyanis minden vizsgált periódusban és mind a négy típus esetén megjelent.

\section{Az IR publikációk hálózata The network of IS publications}

Azokat a publikációkat, amelyek legalább 30 idézettel rendelkeznek, a közös idézők alapján egy térképen ábrázoltuk a VOSviewer program segítségével. A hálózat csúcsai az idézett közleményeknek felelnek meg, a köztük lévő kapcsolatok erőssége pedig azt mutatja meg, hogy hány publikációban idézték mind a két közleményt. Az ábrán látható, hogy három klaszter alakult ki az innovációs rendszerekkel foglalkozó publikációkon belül. Ezek nagyjából megfelelnek az előzőekben bemutatott irányzatoknak azzal a különbséggel, hogy a szektorális innovációs rendszerek nem alkotnak különálló csoportot. 


\section{2. ábra: Az IR-ek irodalmának közös idézettség alapján kialakuló hálózata \\ Figure 2. Co-citation network of the IS literature}

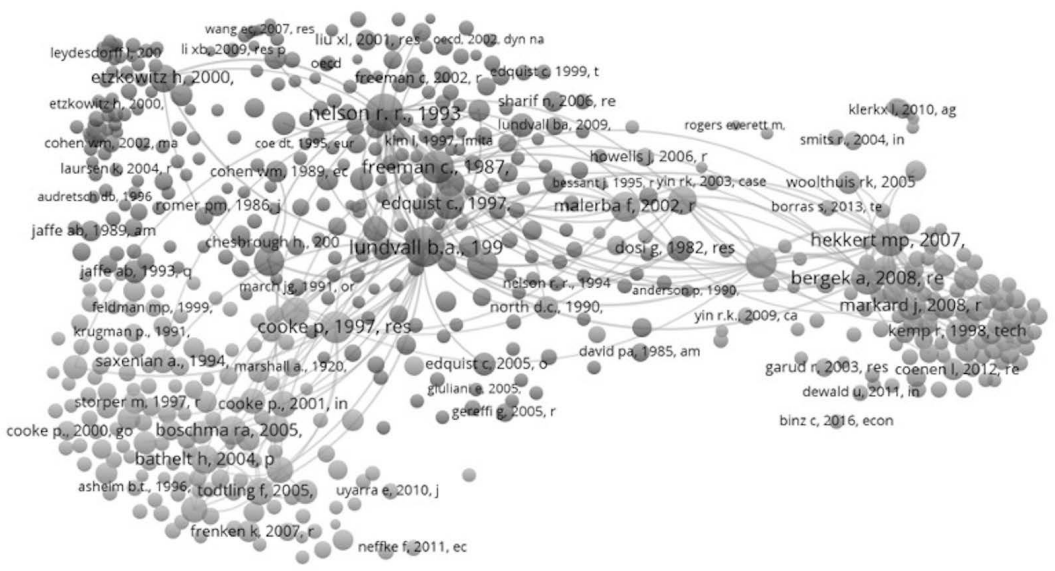

Forrás: a Web of Science adatai alapján saját szerkesztés

Az első klaszterbe a nemzeti innovációs rendszerekkel foglalkozó mủvek kerültek. Ezek közül a legtöbbet idézett publikációk az elméletet meglapozó három szerzőhöz kötődnek: Nelson (1993), Lundvall (1992) és Freeman (1987). A klaszter periférikus részén megtalálható egy kisebb csoportban az Etzkowitz és Leydesdorff (2000) munkásságához kötődő Triple Helix irányzat.

A második klaszter a regionális innovációs rendszerek szakirodalmát fedi le. Itt a három legtöbbet idézett publikáció Cooke és szerzőtársai (1997) alapműve, Porter (1990) versenyelőnyökkel foglalkozó írása, valamint Tödtling és Trippl (2005) RIR-ek különböző típusai esetén alkalmas szakpolitikákat bemutató elemzése.

A harmadik klasztert a technológiai innovációs rendszerekhez sorolható publikációk alkotják. Idézettség alapján Hekkert és szerzőtársai (2007), valamint Bergek és szerzőtársai (2008) művei kiemelkedőek, amelyekben bevezetik a TIR-ek funkcionális megközelítésének sémáját. Itt jelenik meg harmadikként a szektorális innovációs rendszerek alapműve, Malerba (2002) tanulmánya is. Malerba összes többi műve viszont a NIR-ek klaszterébe került. Ebből látszik, hogy a négy irányzat közül egyedül a SIR nem alkot külön csoportot, hanem a nemzeti és a technológiai innovációs rendszerek határán helyezkedik el. A citációs adatok alapján is az látható, hogy a NIR-ek és a RIR-ek irodalma közel áll egymáshoz. A TIR-ek ehhez képest távolabb helyezkednek el, és elsősorban a NIR klaszterhez kapcsolódnak.

\section{AZ IR KUTATÁSOK ÚJ KIHÍVÁSAI NEW CHALLENGES IN IS RESEARCH}

Az IR kutatásoknak alkalmazkodniuk kell az innováció jellegének és értelmezésének megváltozásához annak érdekében, hogy továbbra is releváns elméleti keretet maradhasson. Egyre nagyobb jelentősége van ugyanis a társadalmi-technikai rendszerek transzformációjának, valamint azt is láthatjuk, hogy az innovációs folyamat egyre inkább nyílt, interaktív és globális jelleget ölt. Másrészt az innovációs politika elvárásai is változtak, ezért ma már nem csak a versenyképesség növelése a cél, hanem jelentős társadalmi, környezeti és fejlődési kérdésekre is reagálnia kell a politikának (Weber \& Truffer 2017). 


\section{Az innováció globális jellege The global nature of innovation}

Az innovációs rendszerek vizsgálata a nemzetek termelési rendszereinek elemzéséből alakult ki, de már a koncepció megjelenésekor is igaz volt, hogy a globalizáció és regionalizáció jelensége egyaránt a nemzeti szint gyengülését okozza. Bizonyos esetekben a régió, mint elemzési szint sokkal inkább megfelel az innováció létrejöttének és terjedésének megragadására, ami a RIR kutatásokat létjogosultságát igazolja (Asheim et al. 2011). Számos területen azonban nem lehet az innovációs folyamatot egy régióhoz vagy nemzethez kötni, ugyanis globális szereplők közremüködésével jön létre az új termék vagy technológia. A SIR és TIR megközelítésben éppen ezért nem veszik figyelembe az országhatárokat, hanem az adott iparág vagy technológia fejlödését és terjedését vizsgálják. A globális innovációs rendszerek keretében (Binz \& Truffer 2017) a különböző IR megközelítéseket és az innováció globalizálódó jellegét integrálják. $\mathrm{Az}$ elmélet figyelembe veszi, hogy a nemzeti és regionális környezet sok esetben fontos az innováció kialakulása szempontjából, de a TIR-ekre jellemzö folyamatszemléletet követ. Ebben a keretrendszerben már sokkal jobban megjelenik az innováció nyílt és globális jellege.

\section{Az innováció társadalmi és környezeti hatásai}

\section{The social and environmental impacts of innovation}

Az IR szakirodalomon belül sokáig uralkodott az innováció feltétel nélküli pozitív voltának elfogadása, ezért az innováció iránya nem számított fontos szempontnak. A társadalmi és környezeti hatások vizsgálata csak az elmúlt évtizedben került elötérbe. Tödtling és Trippl (2018) ennek kapcsán olyan új megközelítések létjogosultságára hívja fel a figyelmet, amelyek több figyelmet fordítanak az innováció és a változás irányára és a fenntartható fejlődést biztosító politikákra. Ide tartozik a globális innovációs rendszereket elmélete, a technológiai innovációs rendszerek többszintű perspektívája (multilevel perspective) (Geels et al. 2016) és az átmenet menedzsmentet (transition management) (Kemp \& Never 2017).

Schlaile és szerzőtársai (2017) úgy látják, hogy paradigmaváltásra van szükség az IR keretrendszerében annak érdekében, a normatív megközelítést integrálni lehessen. A fenntarthatóság irányába tartó átmenethez ugyanis meg kell határozni, hogy mi a célja a transzformációnak, és azt milyen úton szeretnénk elérni. Ezen felül legitimálni kell a célt, és meghatározni, ki az, aki megvalósítja a változást, és ki viseli ennek következményeit.

A fenntarthatóság-orientált innovációs rendszerek elmélete (Altenburg \& Pegels 2012) a hagyományos IR megközelítéshez hasonlóan határolja le a rendszert, tehát azok az intézmények tartoznak bele, amelyek hozzájárulnak az új technológia létrehozásához és terjesztéséhez, de ez csak azokra a technológiákra vonatkozik, amelyek segítik a negatív környezeti hatások mérséklését.

A technológiai fejlődés és az ebből következő gazdasági növekedés nem feltétlenül járul hozzá az emberek jólétéhez. Amartya Sen (1993) képességszemléletét beépítve az IR keretrendszerébe (Bajmócy - Gébert 2014) látható, hogy nem elég azt figyelembe venni, hogy az emberi fejlődés eszközei bővülnek-e az innováció által, hanem az is fontos, hogy ezeket képesek-e értékes cselekvésekké és létállapotokká konvertálni.

\section{A szakpolitikai beavatkozások szerepe The role of policy interventions}

A neoklasszikus elmélet szerint a politikai beavatkozások csak a piaci kudarcok korrigálása érdekében lehetnek szükségesek. Az innováció rendszerszerủ megközelítése szerint viszont nem csak a piaci kudarcok, hanem a rendszerkudarcok is indokolhatják a beavatkozást. Ezek közé tartozik a képesség kudarca, a koordinációs vagy hálózat kudarc, az intézményi kudarcok, valamint az elégtelen infrastruktúra (Weber \& Truffer 2017). A rendszerkudarcok speciális fajtái a transzformációs vagy átmenetkudarcok (transformational system failures), amelyek a társadalmi-technikai rendszerek átalakulása és az új út fejlesztés (path development) kapcsán merülhetnek fel, és kezelésükben szerepe lehet az innovációs politikának (Weber \& Rohracher 2012). A fenntarthatóságorientált innovációs rendszerek szemlélete szerint a szakpolitikának fontos szerepe van, mivel nem fenntartható technológiák helyett támogatnia kell az alternatív megoldásokat, amelyek azonban még sokáig nem járnak gazdasági megtérüléssel (Altenburg \& Pegels 2012). 


\section{ÖSSZEGZÉS SUMMARY}

Jelen irodalomelemzés alapján elmondható, hogy az elmúlt harminc évben széles körben elterjedt a szemlélet, miszerint az innováció nem elszigetelt vállalatok teljesítményének eredménye, hanem különböző szereplök interakciói során, meghatározott intézményi környezetben valósul meg. Mindazonáltal úgy tünik, hogy az IR koncepció már túl van a legdinamikusabb terjedésén, és számos kihívással kell megküzdenie annak érekében, hogy releváns elemzési keret maradjon az innovációkutatás újabb szempontjai szerint is.

A szakirodalom számszerüsíthető adatainak vizsgálata rámutat arra, hogy a leggyakoribb a területi alapú innovációs rendszerek vizsgálata, de a TIR kutatások jelentősége is egyre növekszik, elsősorban a társadalmi-technikai rendszerek átalakulása és a fenntarthatóság irányába vezető technológiák terjedése kapcsán. A leggyakoribb kulcsszavak, valamint a citációs adatok alapján elmondható, hogy a négy irányzat közül a nemzeti és a regionális innovációs rendszerek koncepciója áll legközelebb egymáshoz. A technológiai innovációs rendszerek irodalmában ezzel szemben sajátos kérdéseket dolgoznak fel, ezért eltérő kulcsszavakkal találkozhatunk. A szektorális innovációs rendszerek gyenge súlyát mutatja, hogy a közös idézettség alapján kialakuló hálózatban a nemzeti, regionális és technológiai innovációs rendszerek önálló klasztert alkotnak, viszont a szektorális változat nem jelenik meg önálló csoportként.

Megállapítható, hogy az IR szakirodalmon belül komoly törekvések vannak az innováció árnyaltabb értelmezésére. Az innováció feltétel nélküli pozitív voltának elfogadása helyett a társadalmi és környezeti hatásokat is figyelembe vevő irányzatok IR keretbe való integrálására több megközelítés is született, mint például a fenntarthatóság-orientált innovációs rendszerek. Annak ellenére, hogy ezek fontos szerepet játszanak abban, hogy az IR mint keretrendszer alkalmazkodni tudjon az innovációkutatás aktualitásaihoz, még nem terjedtek el nagy számban az ezzel foglalkozó tanulmányok. 


\section{HIVATKOZÁSOK REFERENCES}

Altenburg, T. \& Pegels, A. (2012), "Sustainability-oriented innovation systems-managing the green transformation". Innovation and Development, 2(1), 5-22. DOI: 10.1080/2157930x.2012.664037

Asheim, B.T., Grillitsch, M. \& Trippl, M. (2016), Regional innovation systems: past - present - future. In Handbook on the geographies of innovation, 45-62. DOI: 10.4337/9781784710774.0001

Asheim, B.T., Smith, H.L. \& Oughton, C. (2011), "Regional innovation systems: theory, empirics and policy." Regional Studies, 45(7), 875-891. DOI: 10.1080/00343404.2011.596701

Bajmócy, Z. \& Gébert, J. (2014), "The outlines of innovation policy in the capability approach". Technology in Society, 38, 93102. DOI: 10.1016/j.techsoc.2014.02.004

Braczyk, H.J., Cooke, P.N. \& Heidenreich, M. (Eds.). (1998), Regional innovation systems: the role of governances in a globalized world. Psychology Press. DOI: 10.4324/9780203330234

Bergek, A., Jacobsson, S., Carlsson, B., Lindmark, S. \& Rickne, A. (2008), "Analyzing the functional dynamics of technological innovation systems: A scheme of analysis." Research Policy, 37(3), 407-429. DOI: 10.1016/j. respol.2007.12.003

Bergek, A., Hekkert, M., Jacobsson, S., Markard, J., Sandén, B. \& Truffer, B. (2015), "Technological innovation systems in contexts: Conceptualizing contextual structures and interaction dynamics." Environmental Innovation and Societal Transitions, 16, 51-64. DOI: 10.1016/j. eist.2015.07.003

Binz, C. \& Truffer, B. (2017), "Global Innovation Systems - A conceptual framework for innovation dynamics in transnational contexts." Research Policy, 46(7), 1284-1298. DOI: 10.1016/j.respol.2017.05.012

Breschi, S. \& Malerba, F. (2005), Sectoral innovation systems: technological regimes, schumpeterian dynamics, and spatial boundaries. In Edquist, C. (2005), Systems of innovation: technologies, institutions and organizations. Routledge. 131-156.

Carlsson, B. (ed.) (1995), Technological Systems and Economic Performance. Dordrecht: Kluwer.
Carlsson, B. \& Stankiewicz, R. (1991), "On the nature, function and composition of technological systems." Journal of Evolutionary Economics, 1(2), 93-118. DOI: 10.1007/bf01224915

Cooke, P. (1992), "Regional innovation systems: competitive regulation in the new Europe." Geoforum, 23(3), 365-382. DOI: 10.1016/00167185(92)90048-9

Cooke, P., Uranga, M.G. \& Etxebarria, G. (1997), "Regional innovation systems: Institutional and organisational dimensions." Research Policy, 26(4-5), 475-491. DOI: 10.1016/s00487333(97)00025-5

Doloreux, D. \& Porto Gomez, I. (2017), ”A review of (almost) 20 years of regional innovation systems research." European Planning Studies, 25(3), 371-387. DOI: 10.1080/09654313.2016.1244516

Edquist, C. (ed.) (1997), Systems of Innovation. London: Frances Pinter. DOI: 10.4324/9780203357620

Fagerberg, J. \& Sapprasert, K. (2011), ”National innovation systems: the emergence of a new approach." Science and Public Policy, 38(9), 669-679. DOI: $10.3152 / 030234211 \times 13070021$ 633369

Etzkowitz, H., \& Leydesdorff, L. (2000), "The dynamics of innovation: from National Systems and "Mode 2" to a Triple Helix of university - industry - government relations." Research policy, 29(2), 109-123. DOI: 10.1016/s00487333(99)00055-4

Freeman, C. (1987), Technology policy and economic performance, Pinter: London

Geels, F.W., Kern, F., Fuchs, G., Hinderer, N., Kungl, G., Mylan, J., Neukirch, M. \& Wassermann, S. (2016), "The enactment of socio technical transition pathways: a reformulated typology and a comparative multi-level analysis of the German and UK low carbon electricity transitions (1990-2014)." Research Policy, 45(4), 896-913. DOI: 10.1016/j.respol.2016.01.015

Hekkert, M.P., Suurs, R.A.A., Negro, S.O., Kuhlmann, S. \& Smits, R. (2007), "Functions of innovation systems: A new approach for analysing technological change." Technological Forecasting and Social Change, 74(4), 413-432. DOI: $10.1016 /$ j.techfore.2006.03.002

Inzelt. A (2015), Az innovációs rendszer néhány metszete: cikkgyüjtemény. JATEPress: Szeged

Inzelt, A. \& Bajmócy, Z. (2013), Innovációs rendszerek: Szereplök, kapcsolatok és intéz- 
mények. JATEPress: Szeged

Kemp, R. \& Never, B. (2017), "Green transition, industrial policy, and economic development." Oxford Review of Economic

Policy, 33(1), 66-84. DOI: 10.1093/oxrep/grw037

Liu, Z., Yin, Y., Liu, W. \& Dunford, M. (2015), "Visualizing the intellectual structure and evolution of innovation systems research: a bibliometric analysis." Scientometrics, 103(1), 135158. DOI: $10.1007 / \mathrm{s} 11192-014-1517-\mathrm{y}$

Lundvall, B.Å. (Ed.). (1992), National systems of innovation: Toward a theory of innovation and interactive learning, Pinter: London

Lundvall, B.Å. (2007), "National innovation systems-analytical concept and development tool." Industry and Innovation, 14(1), 95-119. DOI: 10.1080/13662710601130863

Malerba, F. (2002), "Sectoral systems of innovation and production." Research Policy, 31(2), 247264. DOI: 10.1016/s0048-7333(01)00139-1

Malerba, F. \& Adams, P. (2014), Sectoral systems of innovation. In Dodgson, M., Gann, D.M. \& Phillips N. (Eds): The Oxford Handbook of Innovation Management, 183-203. DOI: 10.1093/oxfordhb/9780199694945.013.030

Nelson, R.R. (1993), National innovation systems: A comparative study. Oxford University Press: New York

Pino, R.M. \& Ortega, A.M. (2018), "Regional innovation systems: Systematic literature review and recommendations for future research." Cogent Business \& Management, 5(1), 1463606. DOI: 10.1080/23311975.2018.1463606

Porter, M. E. (1990), "The competitive advantage of nations." Harvard Business Review, 68(2), 73-93.

Rakas, M. \& Hain, D. S. (2019), "The state of innovation system research: What happens beneath the surface?" Research Policy, 48(9), 103787. DOI: 10.1016/j.respol.2019.04.011

Schlaile, M.P., Urmetzer, S., Blok, V., Andersen, A. D., Timmermans, J., Mueller, M., Fagerberg, J. \& Pyka, A. (2017), "Innovation systems for transformations towards sustainability? Taking the normative dimension seriously." Sustainability, 9(12), 2253. DOI: 10.3390/su9122253

Sen, A.K. (1993), Capability and Well-Being. In: Nussbaum, M. \& Sen, A.K. (Eds.): The Quality of Life. 30-53. Oxford University Press, Oxford. DOI: 10.1093/0198287976.003.0003

Tödtling, F. \& Trippl, M. (2018), "Regional innovation policies for new path development-beyond neo-liberal and traditional systemic views." European Planning Studies, 26(9), 1779-1795. DOI: 10.1080/09654313.2018.1457140

Tödtling, F. \& Trippl, M. (2005), "One size fits all?: Towards a differentiated regional innovation policy approach." Research Policy, 34(8), 1203-1219. DOI: 10.1016/j.respol.2005.01.018

Vas, Z. \& Bajmócy, Z. (2012), „Az innovációs rendszerek 25 éve: Szakirodalmi áttekintés evolúciós közgazdaságtani megközelítésben.” Közgazdasági Szemle, 59(11), 1233.

Watkins, A., Papaioannou, T., Mugwagwa, J., \& Kale, D. (2015), "National innovation systems and the intermediary role of industry associations in building institutional capacities for innovation in developing countries: A critical review of the literature." Research Policy, 44(8), 1407-1418. DOI: 10.1016/j.respol.2015.05.004

Weber, K.M., \& Truffer, B. (2017), "Moving innovation systems research to the next level: towards an integrative agenda." Oxford Review of Economic Policy, 33(1), 101-121. DOI: 10.1093/oxrep/grx002

Weber, K.M., \& Rohracher, H. (2012), 'Legitimizing research, technology and innovation policies for transformative change: Combining insights from innovation systems and multi-level perspective in a comprehensive 'failures' framework". Research Policy, 41(6), 1037-1047. DOI: 10.1016/j.respol.2011.10.015 
Varga-Csajkás Anna, tudományos segédmunkatárs csajkas.anna@ktk.pte.hu

MTA-PTE Innováció és Gazdasági Növekedés Kutatócsoport Pécsi Tudományegyetem Közgazdaságtudományi Kar Regionális Innováció- és Vállalkozáskutató Központ (RIERC)

\section{A literature review on innovation systems}

\section{THE AIMS OF THE PAPER}

The systemic concept of innovation is now widespread, which implicates that innovation is considered as the outcome of the interplay between different actors situated in a specific environment. The study aims to introduce this concept and to analyze the literature of the innovation systems. The paper includes the definition of national, regional, technological, and sectoral innovation systems, and the specification of their position in the literature. Besides, the paper examines the new challenges that innovation systems must face.

\section{METHODOLOGY}

This study is a literature review, which consists of three parts. First, we describe the four types of innovation systems according to the most influential publications. Then, we analyze the evolution of the literature with bibliometric tools and describe the relationship between the different types of innovation systems. Finally, we introduce the new theoretical challenges of innovation systems.

\section{MOST IMPORTANT RESULTS}

The results show, although during the last three decades there has been a dynamic rise in the innovation system literature, in the last few years it stopped. It shows that the innovation system approach is beyond its most dynamic expansion. Also, it faces several challenges in order to remain a relevant analytical framework for newer aspects of innovation research. Therefore several approaches have been integrated that take into account the social and environmental impacts of innovation.

\section{RECOMMENDATIONS}

The innovation system as an analytical framework needs to be renewed, but it is still a widespread, relevant concept. In addition to the efforts made so far, further research is needed to enable a broader interpretation of innovation within this framework.

Keywords: innovation systems, literature review, bibliometric analysis

Acknowledgements: This publication/research has been supported by the European Union and Hungary and co-financed by the European Social Fund through the project EFOP-3.6.2-16-2017-00017, titled „Sustainable, intelligent and inclusive regional and city models”. 